\title{
RECENZJA
}

\section{P. Grabowiec, Religia obywatelska jako teoretyczna propozycja integracji politycznej Wspólnoty Europejskiej, Wrocław 2013, ss. 390}

DOI: http://dx.doi.org/10.21784/ZC.2014.015

ISSN: 1896-4087

\section{Pełny tekst:}

PDF - 359-362

Praca Piotra Grabowca stanowi kontynuację jego wieloletnich dociekań naukowych na temat myśli politycznej, społeczeństwa obywatelskiego czy kulturowych i cywilizacyjnych uwarunkowań polityki. Tym razem autor przygląda się szansom dalszej integracji politycznej Wspólnoty Europejskiej, zauważając, że pogrążona w kryzysie UE stoi dziś przed koniecznością utrzymania i wzmocnienia tożsamości, w czym pomocna byłaby religia obywatelska. Działania integracyjne są potrzebne, jeśli Europa chce realizować marzenia o rozwoju i silnej pozycji w zglobalizowanym świecie, a unia walutowa to zbyt mało, by mówić o wspólnocie celów. Grabowiec podkreśla potrzebę odrodzenia cywilizacyjnego Europy, które może się dokonać przez religię obywatelską. Europolis - jak autor nazywa przyszłą, pogłębioną Wspólnotę Europejską - musi się opierać na uniwersalności praw człowieka, tylko takie bowiem fundamenty aksjologiczne mogą uczynić Stary Kontynent cywilizacyjnie atrakcyjnym obszarem świata.

Książka składa się z czterech rozdziałów (po dwa w obu częściach: teoretycznej i studium przypadku). Pierwszy to interdyscyplinarne rozważania na temat religii, ze szczególnym uwzględnieniem jej miejsca $\mathrm{w}$ politologii oraz roli w polityce. Pośród wielu perspektyw poznawczych pojawia się między innymi politologia religii, subdyscyplina zyskująca popularność przede wszystkim w Stanach Zjednoczonych i na Bałkanach. W rozdziale tym wiele miejsca poświęcone zostało religii obywatelskiej, które to zagadnienie autor wyjaśnia, przywołując stanowiska rozlicznych badaczy. Ów specyficzny typ komunikacji i porozumienia w obrębie wspólnot politycznych naświetlony został na wielu płaszczyznach, w tym nawet na poziomie sportu.

W drugim rozdziale zaprezentowane zostały koncepcje teoretyczne Marceli Cristi (podejście analityczne), Feliksa Konecznego oraz Margaret Archer (podejście morfogenetyczne). Prezentacja spostrzeżeń Marceli Cristi, światowej sławy badaczki zagadnienia religii obywatelskiej, stanowi preludium do analizy elementów myśli Konecznego i Archer. Jak podkreśla autor, Koneczny wyodrębniając kolejne cywilizacje, opierał się na pierwiastku religijnym, dostrzegał przy tym także istotę wiary świeckiej jako czynnika kreującego imaginarium społeczne. Grabowiec doszukuje się u Konecznego projektu religii obywatelskiej dla cywilizacji łacińskiej, a więc idei opartej na tradycji chrześcijańskiej, będącej w stanie zintegrować masy. Z kolei morfogenetyczny model Margaret Archer uznać należy za oryginalne narzędzie analizy zmian politycznych i społecznych, jak i prognozowania potencjalnych scenariuszy rozwoju. Dociekania teoretyczne poparte zostały przykładami Izraela (model liniowy) oraz Włoch (model równoległy). Grabowiec przekonująco wyjaśnia, dlaczego w pierwszym przypadku religia obywatelska została przyjęta i zaakceptowana przez zbiorowość, a w drugim nie.

Rację ma autor sugerując, że zaproponowana przez niego architektura metodologiczna może być przydatna nie tylko $\mathrm{w}$ politologii, ale również w europeistyce. Co więcej, wydaje się, że użyteczność takiego podejścia rozciągnąć można na inne subdyscypliny politologii, tym bardziej 
iż ciągle zbyt mało miejsca poświęca się projekcjom przyszłości, szczególnie w aspekcie jakościowym. Tym samym pracę można uznać za kluczową dla rozwoju polskiej futurologii.

Trzeci rozdział (otwierający część poświęconą analizie przypadków) poświęcony został amerykańskiej religii obywatelskiej, stanowiącej dowód, że możliwe jest zjednoczenie milionów językowo, kulturowo, wyznaniowo i cywilizacyjnie zróżnicowanych jednostek. Grabowiec rzeczowo tłumaczy fenomen powodzenia budowy wspólnoty celów i przekonań, akceptującej przy tym odmienność członków. Dekonstrukcja mitów religii amerykańskiej prowadzi do wniosków na temat specyfiki społeczeństwa, od początku fundowanego na szczególnym systemie wartości. Pośród bardzo wielu ciekawych przemyśleń na szczególne podkreślenie zasługuje kwestia włączenia biopolityki do religii obywatelskiej, w co Waszyngton uwierzył do tego stopnia, że eugenika stała się przedmiotem wykładowym na wielu uczelniach.

Autor zwraca również uwagę na rytuały podtrzymujące religię obywatelską i jej mity w wyobrażeniach zbiorowych Amerykanów. Wiara w wyjątkowość narodu i jego predestynację do odgrywania szczególnej misji w dziejach świata musi być ciągle pielęgnowana, a w procesie tym istotną rolę odgrywa polityka pamięci. Rozważania na temat Stanów Zjednoczonych Grabowiec zamyka uwagami na temat edukacji i sportu jako form socjalizacji i wychowania patriotycznego. Autor wykazuje, że amerykańskie szkolnictwo stanowi jeden z filarów religii obywatelskiej, a nauczyciele maj za zadanie wychowanie jej szczerych i oddanych wyznawców. Podobną funkcję pełni sport, a w szczególności „święta trójca” najważniejszych dyscyplin: futbol amerykański, bejsbol , koszykówka.

Ostatni rozdział dotyczy religii obywatelskiej przyszłego Europolis czy też Stanów Zjednoczonych Europy. Jeśli Wspólnota zechce się bardziej zintegrować, a taki proces jest według autora konieczny, zachodzi potrzeba konsolidacji społeczeństw wokół wspólnej idei. Przykład USA może być pomocny, ale analogie w pewnym momencie się kończą. Jak zauważa Grabowiec, przybywający za ocean imigranci nie mieli wyjścia i musieli dokonywać konwersji na religię amerykańskości. Tymczasem napływająca dziś do Europy ludność nie odczuwa potrzeby integracji, postęp cywilizacyjny i powszechność Internetu sprawiły bowiem, że łatwa jest łączność ze „starym światem”. Dla przybyszów Europa nie jest atrakcyjna aksjologicznie, a bez porozumienia na płaszczyźnie wartości i celów nie można zbudować wspólnoty. Autor sugeruje więc modele działań, których implementacja pomogłaby zbudować obywatelski naród narodów. W poszukiwaniu złotego środka Grabowiec proponuje oparcie się na fundamentach etyki świata zachodniego z jego trzema symbolami - Atenami, Rzymem i Jerozolimą. Taka postać religii obywatelskiej mogłaby być atrakcyjna dla ogółu mieszkańców Europolis z uwagi na uczynienie praw człowieka jej najważniejszym filarem. Nowym, czwartym symbolem byłaby Bruksela oznaczająca patriotyzm konstytucyjny.

Niewątpliwym walorem pracy jest jej interdyscyplinarny charakter. Autor, zauważając, że politologia wymaga wiedzy integralnej, wykorzystuje również elementy innych nauk, w tym socjologii, antropologii, psychologii, teologii. Na szczególne podkreślenie zasługuje bogata literatura przedmiotu, w której nie brakuje źródeł obcojęzycznych. Na gruncie polskiej politologii ciągle zbyt mało jest publikacji opartych na jakościowych czynnikach zmian, tak więc niniejsze opracowanie wnosi niemały wkład w rozwój nauki.

Książkę uznać należy za wyjątkowo ciekawą, szczególnie w kontekście debat nad polityczną, demograficzną i kulturową przyszłością coraz bardziej wielokulturowej Europy. Rozważania teoretyczne, a także przykłady praktyczne skłaniają czytelnika do samodzielnych przemyśleń na temat perspektyw powstania Europolis. Wyszczególnione na końcu postulaty wydają się oryginalnym pomysłem wykreowania europejskiej religii obywatelskiej.

Grabowiec słusznie zauważa, że nie będzie to łatwe i zapewne konieczne okaże się zawieranie kompromisów. Jednakże wypracowanie akceptowalnej dla wszystkich formuły jest koniecznością, pogrążona bowiem w kryzysie Europa potrzebuje cywilizacyjnej odnowy. 